\title{
SOCIO-ECONOMIC CONSTRUCTION OF DOWRY AMONG RURAL WOMEN OF HARYANA (INDIA)
}

\author{
Subhash Chander, Jatesh Kathpalia, Vinod Kumari \\ Department of Sociology \\ Chaudhary Charan Singh Haryana Agricultural University, Hisar, Haryana
}

\begin{abstract}
The practice of dowry is widespread in India and refers to the payment of cash/gifts by the bride's family to the bridegroom's family before marriage. Though prohibited by law, dowry is widely practiced, and often contributes to severe injuries and even death of young brides. This study examined the various aspects of nature and extent related to dowry among rural women of Karnal district of Haryana. It was found from the field of the study that out of 200 respondents, 10.5 per cent faced the problem related to dowry. The maximum number of cases regarding dowry demand were made by mother-in-laws (76.19\%). Main demands for dowry were of cash money (57.14\%). The maximum number of the respondents $(42.86 \%)$ reported physical violence followed by verbal abuse (38.09) and psychological/emotional $(28.57 \%)$. It was also suggested that Voluntary organizations and Gram Panchayats should come forward to work for the abolition of dowry system in Haryana. They should make propaganda against the evils of dowry.
\end{abstract}

Key words - Nature, extent, problem of dowry, dowry demand, reasons for demanding dowry, violence etc.

\section{INTRODUCTION}

In a crime that is prevalent only in India, greedy husbands and his relatives harass the newly wed bride for getting more dowry, and often kill her in the process. And, very often, she is burnt alive. This horror is therefore called bride-burning or in official terms, dowry death. In 2010, there were 8391 reported cases of dowry death in the country. That works out to a shocking one death every hour approximately. Bride-burning is on the increase - just a decade ago, in 2000 , there were 6995 cases. Dowry is an ancient tradition among the upper castes but its spread among all sections of society probably in the late nineteenth century. With increasing commercialization this acquired a new meaning - it became an opportunity for men and their families to get their hands on cash, jewellery, durables, and various other commodities. Although the government prohibited dowry through legislation in 1961, it was never implemented properly. Prohibition officers were supposed to have been appointed in each district, taking the battle to the grassroots but nothing happened. And, the tide of greed driven murder of young brides continued unabated. After all, conviction rates in bride burning cases have dipped from an already weak $37 \%$ in 2000 to $34 \%$ in 2010 . In section 498A cases, the conviction rates are even lower: just 19\%, although reported cases were 94,000 in 2010 (Verma, 2012).

Human rights represent the right of all human beings of sexes, men and women. Women represent about half of total population and gender inequality and biasness are main features of rural society. The night of women in general is distressing and their conditions in society are not so good. Even today, women are not enjoying as such freedom and liberties as men do. Crime against women is increasing day by day. There has been constant rise in dowry deaths, rape, molestation, torture, sexual harassment and domestic violence. NCRP reported 8618 dowry deaths in 2012. With Govt., initiates and women's own efforts their status is improving.

Marriage is an auspicious ceremony which units two bodies and soul into one. It is lifelong bonding of male and female. The demand of dowry or dowry system is a deep rooted problem in our society. The dowry system is a cultural system in India in which parents of bride pay a huge sum of money jewellery, gift and other household items to the parents of groom before marriage, during and after marriage. Dowry has an impact of women's marital life. It is multi-faceted, deep rooted gender issue with socio-psychological economic and health consequences. The social and cultural effect of dowry system are devastating to 


\section{International Journal of Engineering Applied Sciences and Technology, 2020 \\ Vol. 4, Issue 12, ISSN No. 2455-2143, Pages 610-614 \\ Published Online April 2020 in IJEAST (http://www.ijeast.com)}

society and it is the result of long lasting imbalance of power between men and women.

Dowry system has given rise to many sociopsychological and economic problems with acute and serious consequences. Numerous incidence of bride burning, harassment and physical torture of newly wed women and various kinds of pressure tactics which are being adopted by husband/in-laws family. Government of India enacted "Dowry Prohibition Act, 1961" and which was further amended in 1985 to control this menace. The bride is helpless and powerless in new home to retaliate against the coercive tactics of in-laws and relatives and they do not have guts to give divorce to the husband on ground of physical and mental torture in the name of honour and tradition of family. Rawal and Singh (2014) reported relationship between domestic violence and dowry demands. Forty cases of dowry related domestic violence were studies from Western UP and found that they got married in early age (52.50), rural background, and lower household income $(55.0 \%$ each) and non-working (92.5\%). Majority of cases reported in early years of marriage and were from lower educational background. The study indicated that economic empowerment together with higher education and modified cultural norms may protect the women from such problems (Kumari and Chander, 2019). There are social and economic factors which affect the married life of women. Dowry is associated with women's education and age. It is also a cause of divorce both in urban and rural areas of Punjab. Social factors including women's education, employment, inter-caste marriage, bride's age, are affecting dowry. In this regard, the present study was conducted with the nature and extent about problem of dowry.

Domestic Violence

Rawal Priyanka

and Singh

Jyoti

Practice of Dowry and Domestic Violence

Rawal Priyanka

and Singh

Jyoti

\section{MATERIAL AND METHOD}

The study was conducted in Karnal district of Haryana state. From this district, Asandh block was selected randomly. From the selected block, few villages namely Rahada, Salwan and Kheri Sarf Ali were selected randomly. From the selected villages, 200 respondents were also selected randomly. The questions were framed which clearly indicate their meaning to the respondent and cover relevant aspects of problems according to the objectives of the study. Interview schedule was prepared with the help of various books, bulletins, journals, periodicals, government publications etc. Interview Schedule was prepared to collect the desired information as per objectives of the study. Finally, selected respondents were surveyed with the help of interview schedule. The collected data were coded, tabulated, analyzed and interpreted according to the objective of the present study with the help of appropriate statistical techniques. The descriptive statistical tools such as frequency, percentage and chi-square had been adopted to draw the inference from the study. In the end, the collected data from the field was analysed in term of identifying various specific objectives.

\section{RESULTS AND DISCUSSION}

\section{Problem of dowry among rural women}

Out of 200 respondents, 10.5 per cent faced the problem related to dowry in Table 1. One-third of the respondents $(38.09 \%)$ were demanding dowry before marriage followed by at the time of marriage $(33.33 \%)$ and after marriage (28.58\%). Vermani, et al. (2015) conducted a study on "socio-economic factors affecting the problem of dowry" on 200 women of Haryana (India). They focused on socio-economic and cultural factors affecting the problem of dowry along with constraints. Eighteen per cent women experienced the problem related the dowry after marriage. Major demand for dowry was in form of cash money and vehicle. Majority of women who had problem of dowry were harassed by husband and mother-in-law for dowry. Banerjee (2013) also focused on socio-cultural face of exploitation by dowry in modern India.

The maximum number of cases regarding dowry demand were made by mother-in-laws (76.19\%) followed by their husbands $(42.86 \%)$ and father-in-laws (19.04\%). Kathpalia et al. (2018) conducted a study on two hundred rural women of Haryana (India) entitled "domestic violence against women in rural communities of Haryana". They found from the field of the study that nearly three-fifth of rural women were facing the problem of domestic violence in various form namely slapping, pushing, twisting arm, beating, screaming rage, becoming angry, taunting, insulting etc. Ghosh and Choudhury (2011) were also examined the legal protection against domestic violence in India. 
Table 1: Various aspects of nature and extent related to dowry $(\mathbf{n}=\mathbf{2 0 0})$

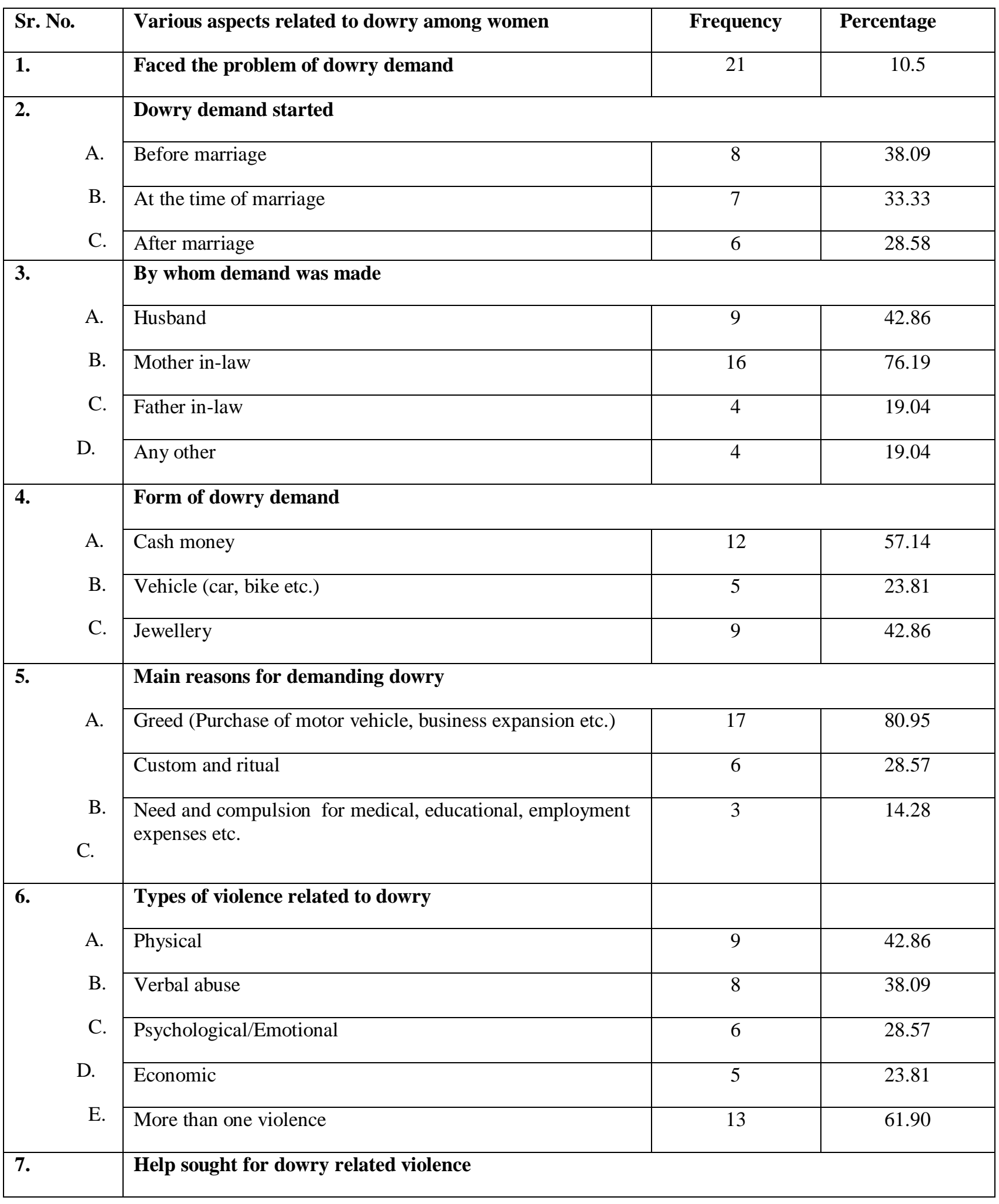


International Journal of Engineering Applied Sciences and Technology, 2020

Vol. 4, Issue 12, ISSN No. 2455-2143, Pages 610-614

Published Online April 2020 in IJEAST (http://www.ijeast.com)

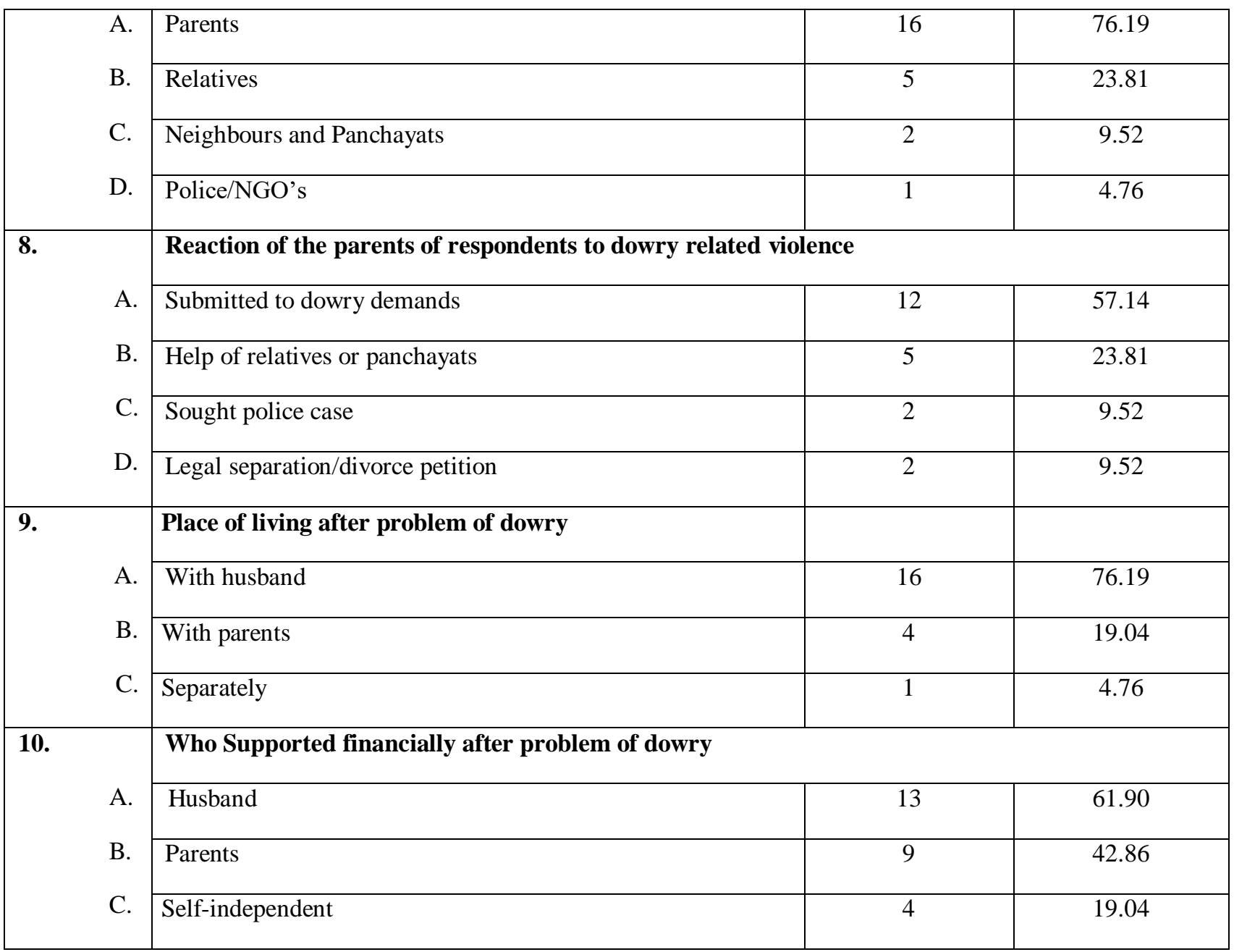

Responses were multiple

Respondents who had the problem related to dowry, main demands for dowry were of cash money (57.14\%). Similarly, jewellery $(42.86 \%)$ and vehicles like car, bike etc. $(23.81 \%)$ were also demanded.

The data analysis regarding reasons for demanding dowry revealed that the core reason for dowry was greed $(80.95 \%)$ like purchase of motor vehicles, business expansion, employment etc. Customs and rituals (28.57\%) were also found reason for dowry. However, for satisfying the needs and compulsion for medical treatment, educational expenses etc. (14.28\%) were the reason for dowry.

The respondents suffered various types of violence related to dowry. Analysis revealed that maximum number of the respondents (42.86\%) reported physical violence followed by verbal abuse (38.09) and psychological/emotional (28.57\%). On the other hand, 61.90 per cent also reported more than one mode of violence against them
The respondents were further asked about the help sought by them on experiencing dowry related violence. More than three-fourth of the respondents (76.19\%) sought help from parents. Kathpalia et al. (2019) conducted a study on two hundred rural women entitled "problem of eve-teasing among rural women in Haryana". They examined nature and extent, factors affecting the practice of eve-teasing. Eve-teasing was found most frequent crime against women. Majority of women were facing it frequently in the field. Public transport namely buses, train etc. were common place for eve-teasing followed by on farm, hand pump and well.

The reaction of the parents of the respondents to dowry related violence showed that $57.14 \%$ fulfilled to dowry demands. Remaining $23.21 \%$ respondents sought help of relatives or panchayats and 19.04 per cent reported the matter to the police or court. Kumari and Chander (2018) conducted a study on "knowledge of women regarding the laws against crime" in Haryana. They focused on knowledge and 
International Journal of Engineering Applied Sciences and Technology, 2020

Vol. 4, Issue 12, ISSN No. 2455-2143, Pages 610-614

Published Online April 2020 in IJEAST (http://www.ijeast.com)

awareness about the laws related to crime against women. It was found that knowledge and awareness about laws related to particular crime was low on various acts namely The Special Marriage Act, The Hindu Succession Act, Protecting the dignity of women etc.

More than three-fourth of the respondents (76.19\%) had problem related to dowry were living with husband and $19.04 \%$ with parents. Laroiya and Arya (2017) focused on impact of eve-teasing on selfconfidence and wellbeing among rural adolescent girls of Haryana.

More than three-fifth of the respondents (61.90\%) were financially supported by husband after having this problem and 42.86 per cent by parents. Tyagi et al. (2017) conducted a study on "Impact of crime on women and their families in rural areas" in Haryana. They focused on consequences of crime on victim women and their families. Two-third of the respondents in the field felt anxiety followed by atmosphere unsuitable for children and denial of human rights/basic needs by husband. The societal consequences were affected relationship with friends and neighbours.

\section{CONCLUSION}

It was concluded that the custom of dowry among Hindu created various problems in the society in marrying daughters. Hence in order to abolish the custom of dowry the Government enacted Dowry Prohibition Act on 20th May 1961. Special efforts are to be made by every institution to motivate people to act for the effective implementation of legislative measure to combat the menace of dowry system from our society. Social consciousness about the ill effects of dowry system needs to be aroused. Youths are the only ray of hope to combat effectively the menace of dowry system. They should take a pledge to boycott those boys who ask for dowry to marry them.

\section{ACKNOWLEDGEMENT}

This research was supported by Government of Haryana for financial assistance. We thank the office-bearers of Directorate of Research from Chaudhary Charan Singh Haryana Agricultural University, Hisar who provided insight and expertise that greatly assisted the research. We also thank to Dr. Savita Vermani, Former Professor and Head, Department of Sociology for assistance of descriptive statistical techniques that greatly improved the manuscript. I also wish to acknowledge your continued support for the agreement state program.

\section{REFERENCE}

1. Banerjee, P. (2013). Dowry in 21st century India: the socio-cultural face of exploitation, Trauma Violence Abus., 15 (1): (pp. 34-40).

2. Ghosh, B., and Choudhury, T. (2011). Legal protection against domestic violence in India: scope and limitations, J. Fam. Violence, 26: (pp. 319-330).

3. Jyoti Kathpalia, J., Chander, S. and Kumari, V. (2018). Rural women and domestic violence - A sociological study of Haryana. International Journal of creative Research Thought. 6 (2) : (pp. 1087-1094).

4. Kathpalia, J., Kumari, V. and Chander, S. (2019). Eve teasing and impact on self-confidence and well being in rural areas of Haryana. International Journal of Education and Management Studies. 9(1): (pp. 49-51).

5. Kumari, V. and Chander, S. (2018). A social psychological study on awareness of rural women and legislative provisions regarding human right. Journal of positive Psychology. 9 (1) : (pp. 29-32).

6. Kumari, V. and Chander, S. (2019). Socioeconomic factors affecting problem of dowry. International Journal of Education and Management Studies. 9(1): (pp. 21-24).

7. Laroiya, C. and Arya, R. (2017) Impact of Eve Teasing on Self Confidence and Well Being Among Rural Adolescent Girls of Haryana. International Journal of Research Culture Society. 1(8): (pp.102-105).

8. National Crime Records Bureau (2012). Govt. of India.

9. Rawal Priyanka Rawal Priyanka and Singh Jyoti (2014). Practice of Dowry and Domestic Violence, Research Journal of Recent Sciences. 3(IVC): (pp. 95-98).

10. Tyagi, R., Chander, S. and Kathpalia, J. (2017). Impact of crime on women and their families in rural Haryana - A sociological appraisal. Journal of Community Mobilization and Sustainable Development, 14(3): (pp. 415-418).

11. Varma, S. (2012). Dowry death: one bride burnt every hour. Times of India (27th January 2012).

12. Vermani, S., Kathpalia, J. and Chander, S. (2015). Sociological analysis of problem of dowry in rural Haryana. J. of Research, Ext. and Development, 3(6): (pp. 21-25). 